\title{
EXTRACELLULAR AND INTRACELLULAR NUCLEASES IN STAPHYLOCOCCUS AUREUS
}

\author{
J. K. KOHLI, M. S. PATIL, V. N. PANDEY, AND D. S. PRADHAN* \\ Biochemistry Division, Bhabha Atomic Research Centre, \\ Bombay 400 085, India
}

(Received August 28, 1989)

\begin{abstract}
Staphylococcus aureus synthesizes two kinds of intracellular nucleases besides the well-known heat-stable extracellular nuclease. Apparently, these intracellular enzymes have many properties in common with the extracellular nuclease implying that they may have precursor-product relationships. To get an insight into the relationships (if any) the enzymes were purified and their properties were compared. Detailed analysis of the properties together with immunological studies indicated that the enzymes are distinct from one another, so neither of the intracellular nucleases could be a precursor for the extracellular nuclease.
\end{abstract}

Recent research on bacterial exoproteins has shown that a number of these exoproteins have precursors bound to the cell membrane $(4,7,8,15)$. For example, a large molecular precursor of enterotoxin B is present in the cell membrane of $S$. aureus and apparently is a kinetic precursor of the extracellular form of the toxin (19). Also, staphylococcal nuclease is one of the exoenzymes secreted by $S$. aureus cells $(I)$. Its structure-function aspects have been extensively studied $(1,2,16)$. In addition to the extracellular nuclease, $S$. aureus also contains intracellular nucleases $(12,20)$. Apparently, these nucleases show many properties common to the extracellular enzyme, implying a precursor-product relationship. To test this possibility, it was essential to purify these enzymes in order to compare their properties and their extra-intra-cellular relationship. Immunological studies provided compeling evidence that the intracellular and extracellular enzymes may not have common genetic origin so no precursor-product relationships between them may exist.

\section{MATERIALS AND METHODS}

Chemicals. All chemicals were of analytical grade. Brain-heart infusion broth

* Address reprint requests to: Dr. D. S. Pradhan, Associate Director, Biochemical Group, BARC, Bombay 400 085, India. 
(BHIB) was purchased from Difco Laboratories, Detroit, Michigan, U.S.A. Micrococcal nuclease (E.C. 3.1.31.1), calf thymus DNA, 2,5-diphenyl oxazole (PPO), lysostaphin, Hin d III fragments of $\lambda$-DNA, terminal deoxynucleotidyl transferase, poly dT, cyanogen bromide-activated Sepharose-4B, and Freund's complete adjuvant were purchased from Sigma Chemical Co., U.S.A.

Thymidine-methyl-T $\left({ }^{3} \mathrm{H}\right)$ (specific activity $18,500 \mathrm{mCi} / \mathrm{mmol}$ ) was obtained from the Isotope Division, BARC, Bombay. $\alpha-{ }^{32} \mathrm{P}-\mathrm{dGTP}(3,000 \mathrm{Ci} / \mathrm{mmol})$ was purchased from Amersham International plc, England.

Bacterial strain and culture conditions. Staphylococcal aureus ATCC 6538P was maintained on brain heart infusion agar by monthly transfers. $S$. aureus cells were grown in brain heart infusion broth at $37^{\circ} \mathrm{C}$ on a shaker.

Purification of intracellular nucleases. Intracellular nucleases were purified up to $90 \%\left(\mathrm{NH}_{4}\right)_{2} \mathrm{SO}_{4}$ precipitation essentially as described by Vakil et al. (20). The precipitate after $90 \%\left(\mathrm{NH}_{4}\right)_{2} \mathrm{SO}_{4}$ saturation was collected by centrifugation, dissolved in $50 \mathrm{~mm}$ ammonium acetate, $\mathrm{pH}$ 5.9, and dialyzed against the same buffer. The dialyzed solution was clarified by centrifugation and concentrated by polyethylene glycol 600 (PEG). The sample was then dialyzed against $50 \mathrm{~mm}$ ammonium acetate (pH 5.9) to remove PEG. Final purification was by chromatography on phosphorylated cellulose as described by Moravek et al. (9), with some modifications. The sample was loaded on the column $(1.5 \times 3.5 \mathrm{~cm})$ and 2 vol. of buffer were passed. The flow-through showed negligible enzyme activity indicating almost complete binding of the enzyme to the phosphocellulose. The column was then washed with 4 vol. of $0.3 \mathrm{M}$ ammonium acetate, $\mathrm{pH} 5.9$, and a linear gradient $(250 \mathrm{ml}$ each) of $0.3 \mathrm{M} \mathrm{NaCl}$ in $50 \mathrm{~mm}$ ammonium acetate, $\mathrm{pH} 5.9$ and $1 \mathrm{M} \mathrm{NaCl}$ in $50 \mathrm{~mm}$ ammonium acetate, $\mathrm{pH} 8.0$ (titrated to this $\mathrm{pH}$ with $\mathrm{NH}_{4} \mathrm{OH}$ ) was started and $5 \mathrm{ml}$ fractions were collected. Assay of fractions showed two enzyme activity peaks. Peak fractions were separately pooled and lyophilized.

Purification of extracellular nuclease. S. aureus extracellular nuclease was purified according to the procedure described by Moravek et al. (9).

Assay of nucleases. The activities of the nucleases were measured with $\left({ }^{3} \mathrm{H}\right)$-labeled $E$. coli DNA as substrate by the method we developed (5). The assay mixture contained (in $500 \mu \mathrm{l}$ ): $20 \mathrm{~mm}$ glycine- $\mathrm{NaOH}$ buffer $\mathrm{pH} 9.8,100 \mu \mathrm{g}$ bovine serum albumin, $10 \mathrm{~mm} \mathrm{CaCl} 2$ and $15 \mu \mathrm{g}$ of $\left({ }^{3} \mathrm{H}\right)$-thymidine-labeled heat denatured DNA $\left(2.25 \times 10^{5} \mathrm{cpm}\right)$ and suitably diluted enzyme. The assay mixture was incubated at $45^{\circ} \mathrm{C}$ for $15 \mathrm{~min}$. The reaction was terminated by adding $0.1 \mathrm{ml}$ of cold trichloroacetic acid (final conc. 5\%) and the tubes were kept in ice for $30 \mathrm{~min}$ to allow complete precipitation of undigested DNA, then centrifuged $6,000 \mathrm{rpm}$ for $10 \mathrm{~min}$. The radioactivity in acid-soluble supernatant was determined by mixing a 0.1 -ml portion with $10 \mathrm{ml}$ of scintillator $(0.5 \% 2,5$-diphenyl oxazole, $10 \%$ napthalene in 1,4-dioxane) and counted in an LKB 1217 RACKBETA WALLAC liquid scintillation counter. The counting efficiency for $\left({ }^{3} \mathrm{H}\right)$ was $55 \%$.

One unit of enzyme activity is defined as the amount of enzyme which degrades $100 \mathrm{ng}$ of DNA per min under the assay conditions. 
SDS-polyacrylamide gel electrophoresis. SDS-polyacrylamide gel electrophoresis was carried out in $12 \%$ gel according to the method of Laemmli (6). The molecular weights of the proteins were determined by comparing the migration distances of standard proteins of known molecular weights.

DNA degradation patterns of extracellular and intracellular nucleases using ${ }^{32} P$-labeled Poly $d T$ and/or $\lambda-D N A$ as substrates. $3 '-\mathrm{OH}$ end labeling of poly dT and $\lambda$-DNA substrates with $\alpha-{ }^{32} \mathrm{P}$-dGTP by terminal deoxynucleotidyl transferase (TdT) was carried out by the method described by Pandey and Modak (14). The labeled substrates were digested by about 8 units of nucleases in a total volume of $22 \mu \mathrm{l}$ of the standard reaction mixture (described above), except that $5 \mu \mathrm{g}$ of ${ }^{32} \mathrm{P}$-labeled poly dT or $\lambda$-DNA fragment $(16,000 \mathrm{cpm} / \mu \mathrm{g}$ DNA) was used as substrates and the concentration of $\mathrm{Ca}^{2+}$ was reduced to $1 \mathrm{mM}$ to ensure limited digestion. The reaction mixtures were incubated at $45^{\circ} \mathrm{C}$ for different times ranging from 5 to $30 \mathrm{~min}$. The reaction was stopped by adding EGTA to a final concentration of $10 \mathrm{mM}$. After digestion, the samples were mixed with sample loading buffer $(90 \%$ formamide, $1 \times \mathrm{TBE}, 0.02 \%$ bromophenol blue and $0.02 \%$ xylene cyanol). The samples were heated to $90^{\circ} \mathrm{C}$ for $30 \mathrm{~min}$ to denature the DNA then cooled quickly in ice water. Electrophoresis was carried out essentially according to Bacera and Wilson(3) in $20 \%$ acrylamide- $7 \mathrm{M}$ urea denaturing gel using Tris-borate buffer $(0.089 \mathrm{M}$ Tris-borate, $0.089 \mathrm{M}$ boric acid, $0.002 \mathrm{~m}$ EDTA, pH 8.0) in both upper and lower electrode compartments. Electrophoresis was carried out at 1,000 volts until the marker dyes migrated a suitable distance. After electrophoresis, the gel was covered with Handiwrap II and autoradiographed at $-70^{\circ} \mathrm{C}$ using an Indu X-ray film $\left(12^{\prime \prime} \times 15^{\prime \prime}\right)$.

Raising of antibodies against extracellular nuclease. Antibodies were raised against purified preparations (Sigma) of staphylococcal nuclease. The purified enzyme, about $500 \mu \mathrm{g}$ in saline, was emulsified with an equal volume of Freund's complete adjuvant (Difco) and injected into a rabbit at multiple sites. Two weeks after the primary immunization, four booster doses $(500 \mu \mathrm{g})$ were given at intervals of two weeks and the serum was obtained in the second week of the last booster.

Purification of antibodies by affinity column chromatography. The immunized serum was dialyzed against $0.01 \mathrm{M}$ potassium phosphate buffer, $\mathrm{pH} 8.0$, then subjected to DEAE-cellulose column chromatography (2l) using $0.01 \mathrm{M}$ phosphate buffer as eluent. The IgG fraction was then loaded onto a column of $\mathrm{CNBr}$-activated Sepharose-4B, to which staphylococcal nuclease had been bound, to trap the antibodies specific to the enzyme. The column was then washed with phosphate-buffered saline (PBS), pH 7.3. Monospecific antibodies were then retrieved from the column by elution with $0.5 \mathrm{M}$ acetic acid.

Ouchterlony immunodiffusion. Immunodiffusion was carried out essentially according to the method described by Ouchterlony (13).

Rocket immunoelectrophoresis. Rocket immunoelectrophoresis was carried out according to the method: described by Mayer and Walker (10).

Neutralization of enzyme activity with antibodies. Purified extracellular or 
intracellular nucleases were treated separately with purified antibodies for $24 \mathrm{hr}$ at $4{ }^{\circ} \mathrm{C}$. Antigen-antibody complexes were removed by centrifugation and clear supernatants were assayed for enzyme activity using $\left({ }^{3} \mathrm{H}\right)$-thymidine-labeled DNA as the substrate, as described earlier.

\section{RESULTS AND DISCUSSION}

The purification procedures for nucleases from $S$. aureus are detailed in MATERIALS AND METHODS. The cells were lysed with lysostaphin. Treatment of the cell lysate with $1 \%$ Triton $\mathrm{X}-100$ at $30^{\circ} \mathrm{C}$ for $30 \mathrm{~min}$ resulted in a two fold increase in nuclease activity. The cell lysate was fractionated step by step with increasing concentrations of $\left(\mathrm{NH}_{4}\right)_{2} \mathrm{SO}_{4}$. The $90 \%\left(\mathrm{NH}_{4}\right)_{2} \mathrm{SO}_{4}$ fraction was subjected to chromatography on phosphocellulose. Figure 1 illustrates the extent of fractionation achieved by this method. Two activity peaks were obtained upon gradient elution chromatography on phosphocellulose. Peak I appeared at the $0.5 \mathrm{M}$ sodium chloride elution range (fraction No. 22-32) and peak II appeared at the $0.6 \mathrm{M}$ sodium chloride elution range (fraction No. 35-45). The progress of purification of these enzymes is recorded in Table 1. Peaks I and II enzymes were purified 150 - and 200 -fold with an overall yield of 4.7 and $2.1 \%$ respectively.

In the next set of experiments, the properties of the purified intracellular enzymes, peaks I and II, were compared with the extracellular enzyme. The molecular sieving of the extracellular and the intracellular enzymes on Sephadex G-75 column

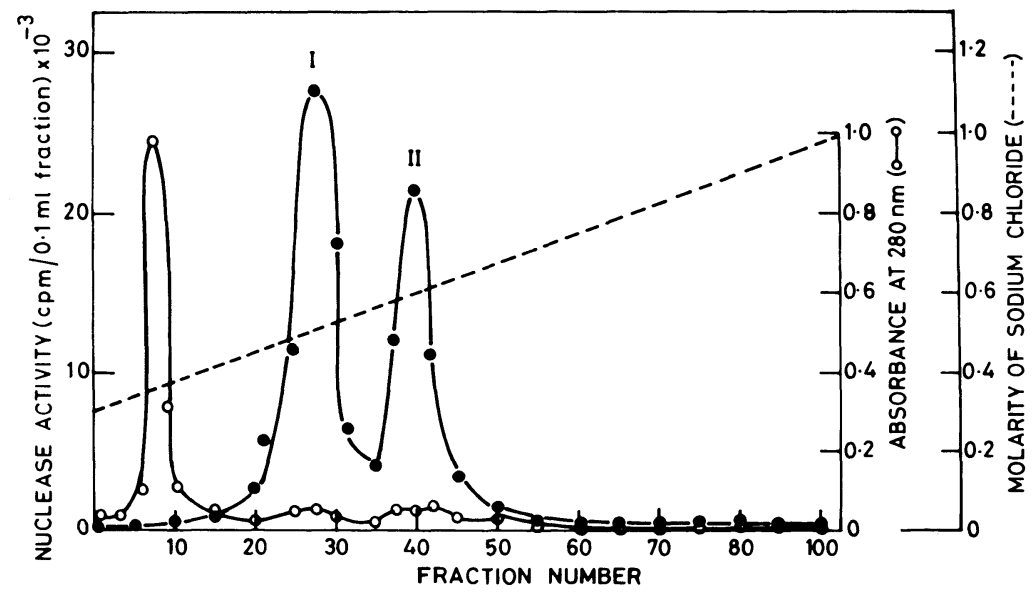

Fig. 1. Elution profile of cellular nuclease on phosphocellulose column. Cellular nucleases, after $90 \%$ ammonium sulphate saturation were loaded on a phosphocellulose column $(1.5 \times 13.5 \mathrm{~cm})$. The enzymes were eluted with a linear gradient formed with $250 \mathrm{ml}$ each of $0.3 \mathrm{M} \mathrm{NaCl}$ in $50 \mathrm{~mm}$ ammonium acetate $\mathrm{pH} 5.9$ and $1.0 \mathrm{M} \mathrm{NaCl}$ in $50 \mathrm{~mm}$ ammonium acetate $\mathrm{pH} 8.0$. Fractions of $5 \mathrm{ml}$ each were collected. The enzyme activity and absorbance at $280 \mathrm{~nm}$ were determined for each fraction. Nuclease activity is expressed as acid-soluble deoxyribonucleotide $\mathrm{cpm}$ formed in the standard nuclease assay. $\bullet$, nuclease activity. 
Table 1. Purification of cellular nucleases.

\begin{tabular}{lcccc}
\hline Step & $\begin{array}{c}\text { Total } \\
\text { protein } \\
(\mathrm{mg})\end{array}$ & $\begin{array}{c}\text { Total } \\
\text { enzyme } \\
(\text { units })^{a}\end{array}$ & $\begin{array}{c}\text { Specific } \\
\text { activity } \\
\text { (units/mg protein) }\end{array}$ & $\begin{array}{c}\text { Recovery } \\
(\%)\end{array}$ \\
\hline $\begin{array}{l}\text { Cell lysate } \\
\text { Precipitate after }\end{array}$ & 4,848 & $4.2 \times 10^{5}$ & 86.6 & 100 \\
$\quad 1,125$ & $2.3 \times 10^{5}$ & 204.4 & 54.7 \\
$\begin{array}{l}\text { Co\% }\left(\mathrm{NH}_{4}\right)_{2} \mathrm{SO}_{4} \\
\text { hromatography on }\end{array}$ & & & & \\
$\quad$ phosphocellulose & & & & \\
Peak I & 1.53 & $2.0 \times 10^{4}$ & 13,071 & 2.76 \\
Peak II & 0.51 & $0.9 \times 10^{4}$ & 17,647 & 2.1 \\
\hline
\end{tabular}

a Nuclease activity was measured using $\left({ }^{3} \mathrm{H}\right)$-thymidine-labeled DNA as the substrate. A one-enzyme unit is as described in MATERIALS AND METHODS.

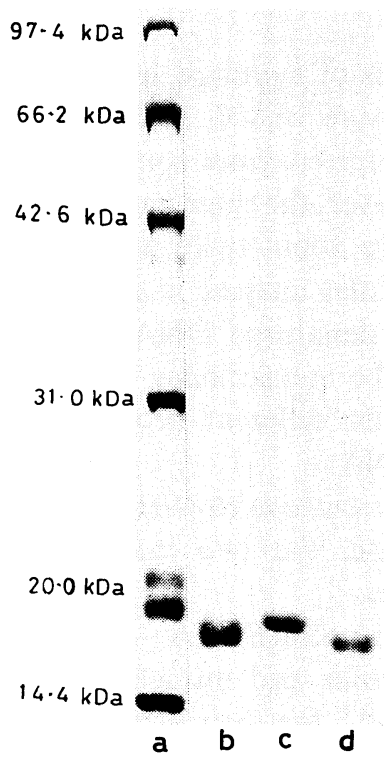

Fig. 2. SDS-polyacrylamide gel electrophoresis pattern of purified extracellular and intracellular nucleases. Twenty $\mu \mathrm{g}$ of each of the purified nucleases were loaded on the gel. Migration of proteins was from cathode ( $-v e)$ to the anode (+ ve): (a) Standard proteins of known molecular weights, (b) extracellular nuclease, (c) intracellular nuclease peak I, (d) intracellular nuclease peak II.

$(2.1 \times 63 \mathrm{~cm})$ showed that the molecular weights of peaks I and II enzymes were similar, in the range of 16,000 to 17,000 daltons (data not shown).

In further experiments, the behavior of the three enzymes - the extracellular enzyme and the peaks I and II enzymes-was studied by SDS-polyacrylamide gel electrophoresis. Figure 2 shows that there are small but significant differences in the relative mobilities of the three enzymes. The molecular weights (calculated by 
Table 2. Spectrophotometric assay of purified nucleases of S. aureus with various substrates.

\begin{tabular}{lccc}
\hline & \multicolumn{3}{c}{ Acid-soluble nucleotides $\left(A_{260}\right)$} \\
\cline { 2 - 4 } Substrate & $\begin{array}{c}\text { Extracellular } \\
\text { nuclease }\end{array}$ & Peak I & Peak II \\
\hline Native DNA & 0.32 & 0.667 & 0.61 \\
Heat-denatured DNA & 0.98 & 0.33 & 0.41 \\
RNA & 0.33 & 0.15 & 0.11 \\
\hline
\end{tabular}

The assay mixture $(1 \mathrm{ml})$, containing $10 \mathrm{~mm}$ glycine- $\mathrm{NaOH}$ buffer $\mathrm{pH} 9.8,200 \mu \mathrm{g}$ of native DNA or heat-denatured DNA or yeast RNA, $10 \mathrm{mM} \mathrm{CaCl}_{2}$ and $0.1 \mathrm{ml}$ enzyme solution containing $1.0 \mu \mathrm{g}$ enzyme protein in $0.1 \% \mathrm{BSA}$, was incubated at $45^{\circ} \mathrm{C}$ for $30 \mathrm{~min}$. At the end of the reaction, undigested DNA was precipitated by adding $0.5 \mathrm{ml}$ of $7 \%$ perchloric acid. Absorbance of the clarified supernatant was measured at $260 \mathrm{~nm}$. Appropriate enzyme and zero time blanks were run along with the assay.

comparing with the mobilities of standard markers) of the extracellular enzyme, and peaks I and II enzymes were 16,800, 17,000 and 15,000 daltons, respectively.

As seen in Table 2, all three enzymes could use native DNA, denatured DNA and RNA as substrates. However, the three enzymes were distinctly different. While the intracellular enzymes were about twice as active as the extracellular nuclease on native DNA, the extracellular enzyme is about three times more efficient than the intracellular enzymes on denatured DNA. The extracellular enzyme was 2-3 times more efficient than the intracellular enzymes in degrading RNA. The intracellular enzymes were also different between themselves in their actions on heat-denatured DNA and RNA.

All three enzymes were insensitive to $N$-ethylmaleimide (NEM), implying that, like the extracellular nuclease, the two intracellular nucleases may not have $\mathrm{SH}$-groups in their active sites.

Ethylene glycol tetraacetic acid(EGTA - a calcium chelating agent) inhibited the activities of the extracellular and intracellular enzymes alike, indicating the obligatory requirement of $\mathrm{Ca}^{2+}$ for their actions. However, the results shown in Fig. 3 reveal small differences among the three enzymes in their requirements of calcium ions. The extracellular enzyme required $10 \mathrm{mM} \mathrm{Ca}^{2+}$ for its maximum activity, whereas the intracellular peak II and peak I enzymes required $20 \mathrm{~mm}$ and $30 \mathrm{~mm} \mathrm{Ca}{ }^{2+}$ respectively for their maximum activities.

$S$. aureus nuclease is an extracellular $5^{\prime}$-phosphodiesterase that yields $3^{\prime}$ mono- and dinucleotides as products of degradation of DNA substrate (16-18). To understand the mechanism of DNA degradation by the intracellular nucleases, it was necessary to compare the modes of degradation of DNA catalyzed by these enzymes with that by extracellular nuclease. The autoradiograms of the nuclease digested poly dT and $\lambda$-DNA products are shown in Fig. 4.

The three enzymes showed interesting differences in their modes of degradation of poly dT and $\lambda$-DNA fragments. With $\lambda$-DNA as substrate, the extracellular 


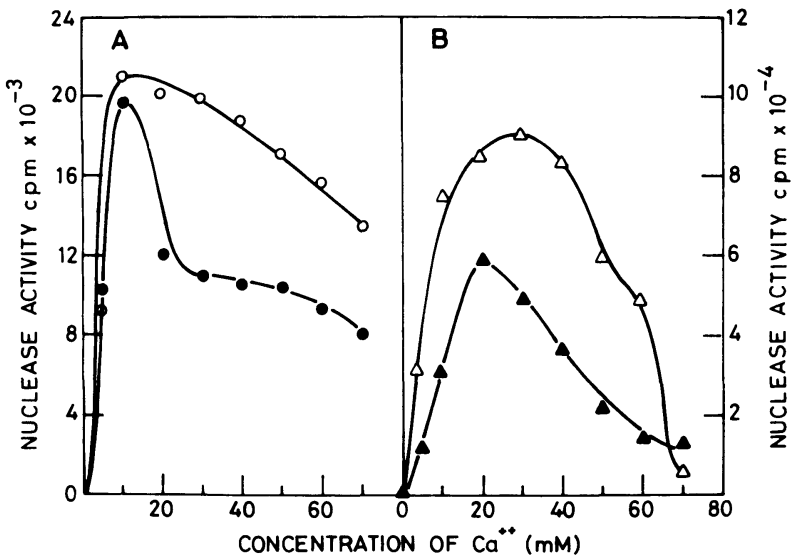

Fig. 3. Effect of divalent cations $\left(\mathrm{Ca}^{2+}\right)$ on the enzymatic activity of extracellular and cellular nucleases. Nuclease was assayed using $\left({ }^{3} \mathrm{H}\right)$-thymidine-labeled DNA as a substrate. The assay mixture contained different concentrations of $\mathrm{Ca}^{2+}$ (in the form of $\left.\mathrm{CaCl}_{2}\right)$ as shown in the figure. Each assay $(0.5 \mathrm{ml})$ contained about $1.0 \mu \mathrm{g}$ each of staphylococcal nuclease (Sigma) or extracellular nuclease or cellular peak I or peak II nuclease enzyme. The nuclease activity is expressed as deoxyribonucleotide cpm formed per assay. (A) $\bigcirc$, staphylococcal nuclease; $\bullet$, extracellular nuclease. (B) $\triangle$, cellular peak I; $\Delta$, cellular peak II.

nuclease action yielded two major fragments 15 and 22 nucleotides long and a minor fragment of 8 nucleotides long at 5, 15 and 30 min digestion and a 13-nucleotide long fragment at 30 min digestion. Peak I intracellular enzyme action did not give major fragments 15 and 22 nucleotides long but yielded two small fragments 8 and 12 nucleotides long at $5 \mathrm{~min}$ digestion. The reaction products also showed a 15-nucleotide long fragment at 15 and 30 min digestion although as a minor component. Peak II intracellular enzyme action, however, in addition to the major 15- and 22-nucleotide long fragments yielded 3-4 fragments 8-13 nucleotides long.

With poly $\mathrm{dT}$ as the substrate, the extracellular nuclease generated two fragments 22 and 15 nucleotides in length. The intracellular enzymes, however, in addition to these fragments give fragments $8-13$ nucleotides in length.

These results convincingly show that the three enzymes are distinctly different in many physicochemical properties and in their modes of actions on different types of DNAs and RNAs.

Further, it was thought that the antibodies to staphylococcal extracellular nuclease could unravel structural similarities between extracellular nuclease and the intracellular nucleases. So the affinity-purified antibodies against Sigma staphylococcal nucleases were tested for their cross-reactivity with the extracellular enzyme obtained from $S$. aureus culture supernatant and the intracellular peaks I and II nucleases by Ouchterlony double immunodiffusion (13) and Rocket immunoelec- 


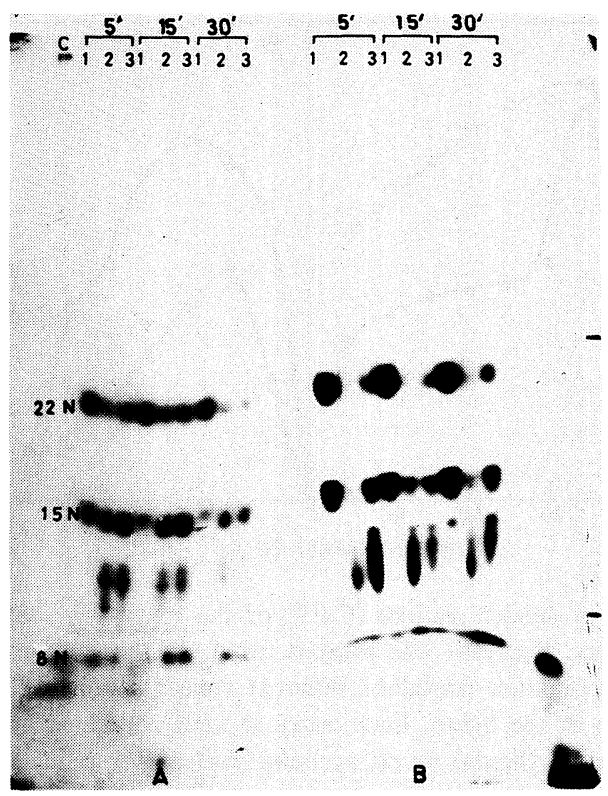

Fig. 4. DNA degradation patterns of extracellular and intracellular nucleases using ${ }^{32} \mathrm{P}$-labeled-poly dT and/or $\lambda$-DNA as substrate. Polyacrylamide gel electrophoresis and autoradiography were carried out as described in MATERIALS AND METHODS. A. DNA degradation with poly $\mathrm{dT}$ as substrate: 1) extracellular nuclease, 2) intracellular nuclease peak I, 3) intracellular peak II. B. DNA degradation with $\lambda$-DNA as substrate: 1) extracellular nuclease, 2) intracellular nuclease peak I, 3) intracellular nuclease peak II.

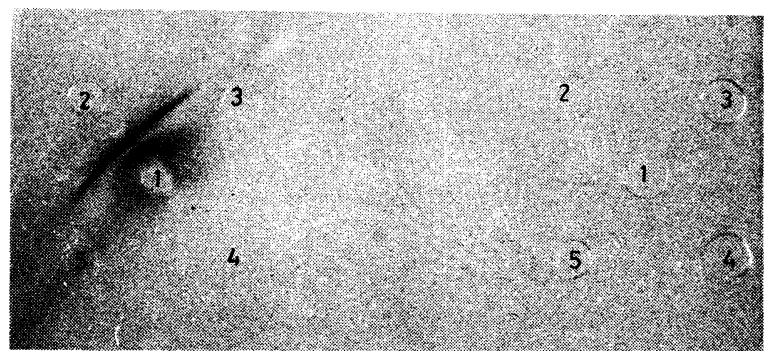

A

B

Fig. 5. Immunological cross-reactivity of purified extracellular and intracellular nucleases with affinity purified antibodies. A. 1) Purified antibodies $(0.5 \mu \mathrm{g} / 10 \mu \mathrm{l}) ; 2)$ extracellular nuclease $(0.5 \mu \mathrm{g} / 10 \mu \mathrm{l}) ; 3)$ intracellular peak I $(0.5 \mu \mathrm{g} / 10 \mu \mathrm{l}) ; 4)$ intracellular peak II $(0.5 \mu \mathrm{g} / 10 \mu \mathrm{l})$; B. 1) Control serum (IgG fraction); 2) extracellular nuclease; 3) intracellular peak I; 4) intracellular peak II.

trophoresis (10). As Figs. 5 and 6 show, peaks I and II nucleases did not cross-react against the purified antibodies. On the other hand, the antibodies strongly reacted with the extracellular enzyme. In further experiments, the monospecific antibodies 


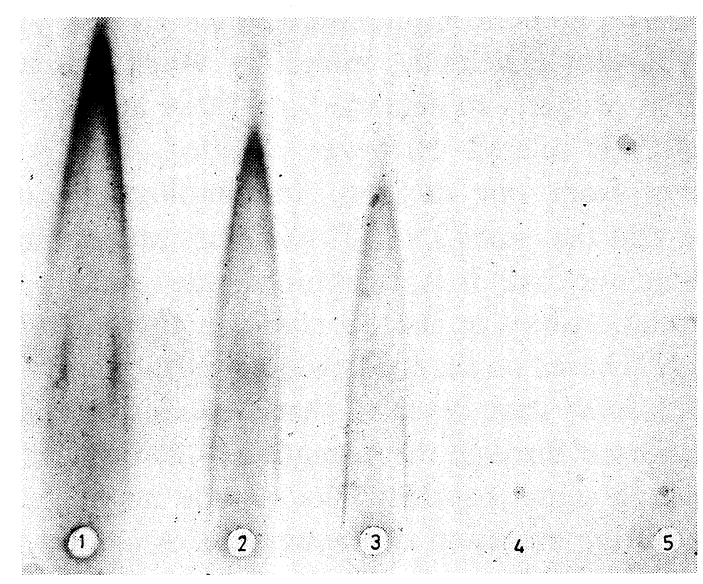

Fig. 6. Rocket immunoelectrophoresis of extracellular and intracellular nucleases. Extracellular nuclease: 1) $20 \mu \mathrm{g}$;2) $10 \mu \mathrm{g}$; 3) $5 \mu \mathrm{g}$; 4) intracellular peak I, $10 \mu \mathrm{g}$; 5) intracellular peak II, $10 \mu \mathrm{g}$.

Table 3. Neutralization of nuclease activity with affinity-purified antibodies.

\begin{tabular}{lccc}
\hline & \multicolumn{3}{c}{ Nuclease activity } \\
\cline { 2 - 4 } Sample & $\begin{array}{c}\text { Untreated } \\
\text { (cpm) }\end{array}$ & $\begin{array}{c}\text { Treated with } \\
\text { affinity-purified } \\
\text { antibodies (cpm) }\end{array}$ & $\begin{array}{c}\text { Inhibition } \\
(\%)\end{array}$ \\
\hline Micrococcal nuclease (Sigma) & 28,818 & 773 & 97.3 \\
Extracellular nuclease & 32,677 & 567 & 98.36 \\
Intracellular nuclease & 30,998 & 29,900 & 3.54 \\
$\quad$ peak I & & 29,150 & 2.47 \\
Intracellular nuclease & & & \\
peak II & 29,890 & & \\
\hline
\end{tabular}

Purified enzyme solutions $(0.5 \mathrm{mg} / \mathrm{ml})$ were treated with equal volumes of affinity-purified antibodies $(0.5 \mathrm{mg} / \mathrm{ml})$ for $18 \mathrm{~h}$ at $4^{\circ} \mathrm{C}$. Samples were centrifuged and the supernatants were assayed for enzyme activity by the assay based on the use of $\left({ }^{3} \mathrm{H}\right)$-thymidine-labeled DNA as substrate.

to staphylococcal nuclease was used to study the effect of their binding on the activities of Sigma staphylococcal nuclease, the extracellular nuclease purified from $S$. aureus culture supernatant and peaks I and II intracellular nucleases. The results (Table 3) clearly demonstrate that the antibodies completely inhibited the activities of Sigma staphylococcal nuclease and purified extracellular nuclease. But the activities of peaks I and II were not affected. These results show that the extracellular enzyme and the two intracellular enzymes are immunologically distinct.

The results presented here demonstrate that the two heat-stable intracellular nucleases (peaks I and II enzymes) have certain properties resembling those of 
extracellular nuclease: monomeric nature, requirement of $\mathrm{Ca}^{2+}$, failure of inhibition of the activities by $N$-ethylmaleimide, molecular weight range of $15,000-17,000$ daltons, heat-stability, property to degrade both DNA and RNA; this implies that they may be structurally related. However, detailed analysis indicated that the enzymes are distinct from one another. Immunological studies also provide compeling evidence that the peaks I and II nucleases are immunologically distinct from the extracellular nuclease. It is, therefore, quite unlikely that they can have precursor-product relationships or share a common cistronic origin.

Recent studies (11) based on the construction and cloning of the staphylococcal nuclease gene in $B$. subtilis have revealed that synthesis of this enzyme may take place at the cell membrane through the formation of an intracellular precursor that has 79 amino-acid-long signal peptide. This peptide might get cleaved at the $B$. subtilis cell surface during excretion of the enzyme. A similar mechanism for the synthesis and secretion of the nuclease is expected to occur in its native habitat, i.e., the $S$. aureus cell. But it was not possible to detect any intracellular nuclease precursor in the cell lysate by the antibodies to staphylococcal nuclease (unpublished observation). There was also no inhibition of the nuclease activity in the intracellular lysate by the antibodies. So a more sensitive approach is necessary to follow the formation of staphylococcal nuclease precursor and its secretion preceded by or followed by cleavage of the signal peptide.

We are thankful to two highly respected educational trusts for financial assistance to Miss J. K. Kohli: 1) The R. D. Birla Smarak Kosh Trust, which awarded a scholarship to her from June 1986 to May 1988; 2) The Lady Tata Memorial Trust, which offered her a Research Fellowship from June 1988.

\section{REFERENCES}

1) Anfinsen, C. B., Cuatrecasas, P., and Taniuchi, H., Staphylococcal nuclease: Chemical properties and catalysis. In Enzymes, ed. by Boyer, P. D., Vol. IV, 3rd ed., Academic Press, New York (1971), p. 177-204.

2) Anfinsen, C. B., Principles that govern the folding of protein chains. Science, 181, 223-230 (1973).

3) Bacera, S. P. and Wilson, S. H., Properties of novel oligonucleotide-releasing bidirectional DNA exonuclease from mouse myeloma. Biochemistry, 23, 908-914 (1984).

4) Engles, W. and Kamps, M. A. F., Secretion of staphylocoagulase by Staphylococcus aureus: The role of a cell bound intermediate. J. Microbiol. Gerol., 47, 509-524 (1981).

5) Kohli, J. K., Vakil, B. V., Patil, M. S., Pandey, V. N., and Pradhan, D. S., A sensitive assay for Staphylococcus aureus nucleases. Indian J. Biochem. Biophys., 26, 296-300 (1989).

6) Laemmli, U. K., Cleavage of structural proteins during the assembly of the head of Bacteriophage $\mathrm{T}_{4}$. Nature, 227, 680-685 (1970).

7) Mantsala, P. and Zalkin, H., Membrane bound and extracellular $\alpha$-amylase from Bacillus subtilis. J. Biol. Chem., 254, 8540-8547 (1979).

8) Mantsala, P. and Puntala, M., Comparison of levansucrase from Bacillus subtilis and from Bacillus amyloliquefaciens. FEMS Microbiol. Lett., 13, 395-399 (1982).

9) Moravek, L., Anfirisen, C. B., Cone, J. L., and Taniuchi, H., The large scale preparation of an extracellular nuclease of Staphylococcus aureus. J. Biol. Chem., 244, 497-499 (1969). 
10) Mayer, R. J. and Walker, J. H., In Immunological methods in the Biological series. Enzymes and proteins, Technical supplement 1, p. 126 (1980).

11) Miller, J. R., Kovacevic, S., and Veal, L. E., Secretion and processing of staphylococcal nuclease by Bacillus subtilis. J. Bacteriol., 169, 3508-3514 (1987).

12) Okabayashi, K. and Mizuno, D., Surface-bound nuclease of Staphylococcus aureus: Localisation of the enzyme, purification and properties of the enzyme. J. Bacteriol., 117, 215-226 (1974).

13) Ouchterlony, O., Antigen-antibody reactions in gels. Acta Pathol. Microbiol. Scand., 25, 507-515 (1949).

14) Pandey, V. and Modak, M. J., Purification of high molecular mass species of calf thymus terminal deoxynucleotidyl transferase. Prep. Biochem., 17, 359-377 (1987).

15) Sargent, M. G., Ghosh, B. K., and Lampeh, J. O., Localization of cell-bound penicillinase in Bacillus licheniformis. J. Bacteriol., 96, 1329-1338 (1968).

16) Tucker, P. W., Hazen, E. E., Jr., and Cotton, F. A., Staphylococcal nuclease reviewed: Correlation of the three dimensional structure with the mechanisms of enzymatic action. Mol. Cell. Biochem., 23, 67-86 (1979).

17) Tucker, P. W., Hazen, E. E., Jr., and Cotton, F. A., Staphylococcal nuclease reviewed: A prototypic study in contemporary enzymology. I. Isolation, physical and ennzymatic properties. Mol. Cell. Biochem., 22, 67-77 (1978).

18) Tucker, P. W., Hazen, E. E., Jr., and Cotton, F. A., Staphylococcal nuclease reviewed: A prototypic study in contemporary enzymology IV. The nuclease as a model for protein folding. Mol. Cell. Biochem., 23, 131-142 (1979).

19) Tweten, R. K. and Iandolo, J. J., Purification and partial characterisation of a putative precursor to staphylococcal enterotoxin B. Infect. Immun., 334, 900-907 (1981).

20) Vakil, B. V., Ramarkrishnan, N., and Pradhan, D. S., Identification of heat-labile cellular nuclease in Staphylococcus aureus with properties similar to the extracellular nuclease (EC 3.1.4.7). Arch. Microbiol., 139, 240-244 (1984).

21) Williams, C. A. and Chase, M. W., Purification of antibody. In Methods in Immunology and Immunochemistry, Vol. I, Academic Press, New York and London (1967), p. 307-385. 